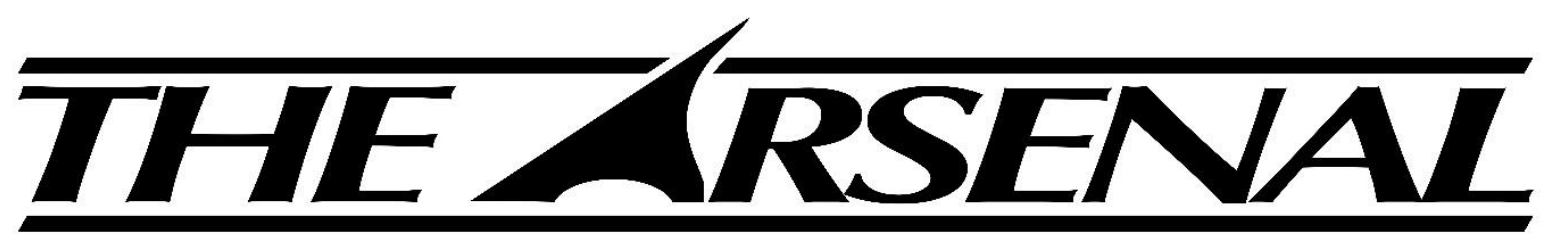

Augusta University's Undergraduate Research Journal

ISSN 2380-5064 | The Arsenal is published by the Augusta University Libraries | http://guides.augusta.edu/arsenal

Volume 4, Issue 1 (2021)

Special Edition Issue

VALIDATION OF A CARBOHYDRATE ANTIGEN-19-9
ENZYME-LINKED IMMUNOSORBENT ASSAY KIT
USING A MOUSE MODEL OF PANCREATIC CANCER

Souravi Mondal and Maria Sabbatini

\title{
Citation
}

Mondal, S., \& Sabbatini, M. (2021). Validation of a carbohydrate antigen-19-9

enzyme-linked immunosorbent assay kit using a mouse model of pancreatic cancer.

The Arsenal: The Undergraduate Research Journal of Augusta University, 4(1), 27. http://doi.org/10.21633/issn.2380.5064/s.2021.04.01.27

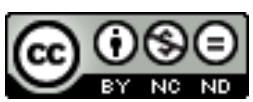

(C) Mondal and Sabbatini 2021. This open access article is distributed under a Creative Commons Attribution NonCommercial-NoDerivs 2.0 Generic License (https://creativecommons.org/licenses/by-nc-nd/2.0/). 


\section{Validation of a Carbohydrate Antigen-19-9 Enzyme-Linked Immunosorbent Assay Kit Using a Mouse Model of Pancreatic Cancer}

Presenter(s): Souravi Mondal

Author(s): Souravi Mondal and Maria Sabbatini

Faculty Sponsor(s): Maria Sabbatini, PhD

Affiliation(s): Department of Biological Sciences (Augusta Univ.)

Funding: Augusta University CURS Student Research Grant

\section{ABSTRACT}

Background: Pancreatic cancer cells express carbohydrate antigen (CA) 19-9. The serum levels of CA 19-9 increase during pancreatic ductal adenocarcinoma (PDAC). CA-19-9 serum levels can therefore be an important biomarker for measuring PDAC progression. There are a number of methods to measure CA-19-9 levels in humans but not in mice.

Aim: to validate the mouse CA-19-9 enzyme-linked immunosorbent assay (ELISA) kit using mouse models of pancreatic cancer in order to study PDAC progression in mice.

Materials and Methods: An ELISA from My BioSource was conducted for CA-19-9 to measure the levels of the antigen. Serum levels of CA-19-9 were measured and compared in healthy mice, mice with chronic pancreatitis (CP), and an orthotopic xenograft model of PDAC in which pancreatic stellate cells (PaSCs) and pancreatic cancer cells were co-injected into the pancreas of immunocompromised NSG mice.

Results: The serum levels of CA-19-9 were elevated in the orthotopic xenograft model of PDAC compared to healthy mice. In mice with CP, the serum levels of CA-19-9 did not change compared to healthy mice.

Conclusion: The kit was validated, and we concluded that this ELISA kit successfully determined that the levels of CA-19-9 increased in mice with pancreatic cancer.

Received: 02/15/2021 Accepted: 03/30/2021

Correspondence: Souravi Mondal, Augusta University, $112015^{\text {th }}$ St. Augusta, GA 30912, smondal@augusta.edu 